\title{
HOSPITALIDADE E CONVIVÊNCIA COMO PRÁTICAS EDUCATIVAS PARA POPULAÇÓES EM SITUAÇÃO DE RUA NO LESTE FLUMINENSE
}

\author{
Lucas Salgueiro Lopes ${ }^{1}$ \\ Débora Simeão Ortman Pereira ${ }^{2}$ \\ Filipi José da Silva ${ }^{3}$ \\ Arthur Vianna Ferreira ${ }^{4}$
}

\begin{abstract}
Resumo: O presente artigo tem como objetivo analisar as práticas socioeducativas realizadas com pessoas em situação de rua sob a ótica, principalmente, das Pedagogias da Convivência de Xesús Jares $(2002 ; 2007 ; 2008)$ e da Hospitalidade de Isabel Baptista $(2005 ; 2008 ; 2011)$. Tendo como base a atuação realizada pela Missão Católica Discípulos de Assis pelas ruas de Niterói-RJ durante o ano de 2018, este trabalho visa conceber novas contribuiçóes acerca dos usos teóricos da Pedagogia Social nas práticas desenvolvidas com populaçóes em situação de rua. Para tanto, enxergamos nos modelos de Jares e Baptista uma forma de empregar práticas interpessoais centradas na convivência comprometidas com uma Educação para a Paz e uma formação cidadã do assistido, tal como, enxergando esse "outro" como um "hóspede", possibilitando uma prática que o faça se sentir acolhido.
\end{abstract}

1 Mestrando em Educação - Processos formativos e desigualdades sociais (PPGEdu) pela Universidade do Estado do Rio de Janeiro (UERJ/FFP). Pós-graduando em Educação Básica Gestão Escolar pela UERJ/FFP. Possui Licenciatura Plena em História pela UERJ e em Sociologia pela UNINTER. Membro do Grupo de Estudos, Ensino e Extensão Fora da Sala de Aula da UERJ/FFP. Bolsista CAPES. E-mail: salgueirollucas@gmail.com.

2 Graduanda em História pela Universidade do Estado do Rio de Janeiro. Bolsista do PIBID (UERJ/ FFP) pelo Projeto "A iniciação à docência e as atividades extraclasse em cursos profissionalizantes de formação de professores de ensino médio no Leste Fluminense", sob orientação do Prof. Dr. Arthur Vianna Ferreira. Membro do Grupo de Estudos, Pesquisa e Extensão Fora da Sala de Aula (UERJ/FFP). E-mail: ortmanffp18@gmail.com.

3 Graduando em Letras (Português/Literaturas) pela Universidade do Estado do Rio de Janeiro. Bolsista monitor da disciplina de Didática da UERJ/FFP. Membro do Grupo de Estudos, Pesquisa e Extensão Fora da Sala de Aula - UERJ/FFP. Professor da Educação Básica. E-mail: filipijoseuerjffp@gmail.com

4 Doutor em Educação: Psicologia da Educação pela Pontifícia Universidade Católica de São Paulo (PUC-SP). Professor adjunto do Departamento de Educação da Faculdade de Formação de Professores da (UERJ/FFP). Pesquisador associado da Fundação Carlos Chagas (FCC-SP). Coordenador-Pesquisador do Grupo de Estudos, Pesquisas e Extensão Fora da Sala de Aula (UERJ/FFP). E-mail: arthuruerjffp@gmail.com. 
Como resultados principais da pesquisa, apontamos as potencialidades e caminhos de uma Pedagogia Social de Rua centrada na convivência com o outro e na construçáo de lugares de hospitalidade materiais e imateriais - junto a esses grupos. Dessa forma, compreende-se a importância de uma formação, inicial ou continuada, para os profissionais da educação que irão trabalhar com esse grupo social específico visando uma formação cidadã que possa educá-los para a luta pela garantia de seus direitos e as suas futuras escolhas dentro da sociedade fluminense.

Palavras-chave: Pedagogia da Hospitalidade; Pedagogia da Convivência; Pedagogia Social de Rua; Práticas socioeducativas; Educação não escolar.

\title{
HOSPITALITY AND COEXISTENCE AS EDUCATIONAL PRACTICES FOR POPULATIONS IN STREET SITUATION AT EAST FLUMINESE
}

\begin{abstract}
This article analyzes the socio-educational practices with street's people from the perspective, mainly, of the Pedagogies of the Coexistence de Xesús Jares $(2002 ; 2007 ; 2008)$ and the Hospitalidade de Isabel Baptista $(2005 ; 2008 ; 2011)$. Based on the work carried out by the Assis' Disciples Catholic Mission through the streets of Niterói-RJ at 2018, this work conceives new contributions about the theoretical uses of Social Pedagogy in the practices developed with homeless populations. For this, Jares and Baptista show a way of employing interpersonal practices centered on coexistence committed to an Education for Peace and citizen formation, such as, seeing this "other" as a "guest" that needs as welcomed. As result of the research, we point the potentialities of a Social Pedagogy centered at the coexistence with the other and the construction of hospitality's places - material and immaterial - together with these groups. Thus, it is understood the importance of training, initial or continuous, for education professionals who will work with this specific social group at a citizen formation that can educate to fight for the guarantee of their rights and future choices at fluminense society.
\end{abstract}

Keywords: Pedagogy of Hospitality; Pedagogy of Coexistence; Social Pedagogy of Street; Socioeducational practices; Non-school education.

\section{INTRODUÇÁO}

A proposta de pesquisa que dá origem a este artigo teve início em 2018, acompanhando as práticas socioeducativas de um grupo de educadores sociais de diversas paróquias pertencentes à Arquidiocese de Niterói, reconhecidos 
posteriormente como uma pastoral social 5 . Tais práticas relatadas aqui compreendem um período de tempo que vai de agosto a dezembro de 2018; o local onde os trabalhos ocorreram foram as ruas do Centro de Niterói ${ }^{6}$, município da regiáo metropolitana do Rio de Janeiro. Esse grupo de agentes acompanhados na pesquisa foi fundado em 2015, sendo nomeado como "Missáo Católica Discípulos de Assis" - e recebendo, depois, a adjetivação de "católica", explicitando a identidade do grupo pastoral. Em Silva (2020), podemos encontrar um pouco da história e do funcionamento da Missáo:

Esse grupo foi fundado pela agente católica, professora e universitária Lara Cristina, com objetivo de viver a radicalidade do Evangelho segundo os passos de São Francisco de Assis (...). Sendo uma organização sem fins lucrativos, o grupo recebia doaçóes - de dinheiro e alimentos - semanal e mensalmente de benfeitores fixos e não fixos. Essas doaçôes, quando recebidas em ocasiôes em que não havia ação voluntária, eram guardadas para as semanas em que houvesse missão. Desse modo, "vivendo da providência", como os agentes afirmavam entre si durante a visita ao grupo, a dedicação não era só material - levar o alimento -, mas afetiva: sentar, conversar, brincar, etc., além de se dedicarem às questóes de garantia de direitos. (SILVA, 2020, p. 188).

A partir desse trecho, conseguimos notar o ponto que mais nos é interessante aqui: a finalidade das práticas socioeducativas desenvolvidas. Para além das necessidades materiais que aqueles assistidos possuíam (como no caso dos alimentos levados), outras demandas eram notadas pelos agentes: o carecimento por uma convivência, por afetividade, tal como a imprescindibilidade por uma prática socioeducativa que tenha por fim uma formação cidadá, de modo, sobretudo, que essas pessoas possam ter a garantia dos direitos legais que possuem - e muitas vezes lhes são negados, omitidos.

É com base nesses pontos que desenvolveremos a proposta deste trabalho: a análise das práticas em Educação Social com pessoas em situação de rua sob a ótica, principalmente, das Pedagogias da Convivência de Xesús Jares (2002; 2007; 2008) e da Hospitalidade de Isabel Baptista $(2005 ; 2008 ; 2011)$. Dessa maneira, trata-se

5 Entende-se nesse caso como "pastoral social" um movimento da instituição religiosa católica apostólica romana que se utiliza de práticas educativas não escolares (no modelo convencionado, "informal") para atuação junto aos grupos sociais empobrecidos. Dessa forma, esses sujeitos atendem as necessidades materiais básicas, assim como estabelecem vínculos educacionais para melhorar a situação de vida em que se encontram os indivíduos, sendo: "Uma ação social (serviço) que multiplica atividades de conscientização, organização e transformação, as quais levam à conversão pessoal, por um lado, e a mudanças concretas de ordem social, econômica e política, por outro. Uma articulação-parceria (diálogo) com as demais igrejas, cristâs e não cristâs, e com as forças vivas que contribuem para transformar a sociedade em que vivemos.”. Disponível em: https://cnbbs2.org.br/pastorais-sociais/. Acessado em 06 de julho de 2020.

6 Município da Regiâo Metropolitana do Rio de Janeiro; $5^{\circ}$ mais populoso do estado (513.584 habitantes estimados para 2019, segundo o IBGE) e 39 mais populoso do Brasil. Está localizado a $15 \mathrm{~km}$ da capital do estado. Segundo o Atlas Brasil (atlasbrasil.org.br) o Índice de Desenvolvimento Humano (IDHM) de Niterói é de 0,837 (em 2010), o que coloca o município na faixa de Desenvolvimento Humano Muito Alto. 
de uma prática inserida no que convenhamos chamar de educação não escolar (cf. FERREIRA; SIRINO; MOTA, 2020) - objeto de estudo da pesquisa científica e educacional dentro do campo da Pedagogia Social (cf. CALIMAN, 2011) e, mais especificamente nesta investigação, parte da subárea denominada Pedagogia Social de Rua (cf. GRACIANI, 1999).

Assim, visto toda a situação de vulnerabilidade e violências sofridas pela populaçáo nas ruas, que tipo de prática o educador social pode oferecer para enfrentar esse infortúnio de tantas carências? Nosso propósito aqui é apontar uma prática educativa centrada na convivência - essa, com valores democráticos e pautados nos Direitos Humanos -, com comprometimento a uma Educação para a $\mathrm{Paz}$ e uma formação cidadã do assistido, enxergando esse "outro", com um papel de "hóspede", onde o indivíduo se sinta acolhido e confortável, criando, assim, lugares (materiais e imateriais) de hospitalidade (cf. BAPTISTA, 2008). É nisso que ambicionamos a hipótese de uma prática educativa que traz consigo a relação, a afetividade, o corpo presente; náo como uma utopia a ser alcançada, mas como um desafio cotidiano a ser praticado pelos educadores sociais no município de Niterói, leste fluminense do Rio de Janeiro.

\section{METODOLOGIA}

A escrita dos diários de campo, que seráo analisados neste artigo, foram realizadas utilizando como metodologia de pesquisa a observaçáo de campo inspirada na fenomenologia do filósofo alemão Edmund Husserl. A fenomenologia, por base do seu significado etimológico (da palavra fenômeno, do grego phainomenon), poderia ser definida como "o discurso sobre aquilo que se mostra como é" (CHINAZZO, 2013, p. 130).

Surgida no século XIX, por influência das ideias do filósofo Franz Brentano, a fenomenologia busca interpretar os fenômenos que chegam à percepção, defendendo a não separação entre sujeito e objeto. Assim, Husserl - discípulo de Brentano -, buscava dar maior consistência científica à filosofia, tendo como uma de suas principais propostas fazer da fenomenologia uma ciência que se ocupasse dos fenômenos de maneira diferente das demais ciências exatas e naturais - visto essas, segundo seguidores da teoria, terem falhado para explicar os fenômenos das ciências humanas (cf. CHINAZZO, 2013). Decorrente disso, Husserl busca "romper com a orientação positivista da sua época", propondo, dessa maneira, "um método filosófico de conhecimento da realidade baseado no empirismo que levasse o sujeito a conhecer, a partir da experiência das realidades e assuntos concretos vividos pelos sujeitos, à essência das coisas de forma consciente" (FERREIRA, 2015, p. 7).

Assim, ao observar o campo de análise da fenomenologia como um "eco" às formas de evidência existentes - essas traduzindo a parte que o sujeito e o mundo das coisas tomam no processo cognitivo - temos três qualidades de intuição, segundo Depraz (2011), da mais à menos formal:

[...] a intuição categorial é puramente formal. Sua verdade é apodítica pelo fato de que ela não faz, em nenhum momento, prova da coisa real; a intuição 
eidética resulta de uma variação perceptiva ou imaginativa dos fatos sensíveis: ela, portanto, toma o real sensível como fio condutor para, mais adiante, dele se livrar em vista da essência desses fatos: partindo da inadequaçáo do mundo sensível, ela tende idealiter ao adequado na busca do invariável; finalmente, a intuição sensível é submetida à contingência do dado e aí experimenta sua fragilidade, sua relatividade: o sujeito afetado se apresenta aqui em toda sua fraqueza passiva... (DEPRAZ, 2011, p. 30).

Partindo da reflexão proposta por Depraz (2011), ao método fenomenológico de Husserl, os diários de campo foram divididos na seguinte estrutura: noema, noese e variação eidética (relacionados, respectivamente, à intuição categorial, intuição sensivel e intuição eidética). Nos diários de pesquisa, então, o noema é relativo à parte mais objetiva do relato de campo, é a descrição do fenômeno de maneira fria, com a percepção mais imparcial possível; o noese é a parte mais subjetiva, onde o sujeito pode descrever o fenômeno a partir de suas lembranças, sentimentos e percepçóes; a variação eidética, por fim, é a maneira de relatar o fenômeno a partir da visão e dos sentimentos dos outros agentes que fizeram parte do fenômeno - sendo uma forma do sujeito relatar a situação de uma forma mais empática, tentando refletir sobre como o fenômeno interferiu sobre o outro (LOPES; FERREIRA, 2019).

\section{PEDAGOGIA SOCIAL, EDUCAÇÃO SOCIAL E AS PRÁTICAS SOCIOEDUCATIVAS NAS RUAS}

Ainda que a área da Pedagogia Social (PS) esteja sendo recentemente institucionalizada no Brasil, os estudos sobre Pedagogia e Educação Social são realizados desde o século XX, em diversos países. Como visto em Hans Uwe-Otto (2011, p. 29), educadores alemães (tais como Karl Mager e Adolph Diesterweg) discutem sobre o conceito de Pedagogia Social desde meados de 1900. Neste século $\mathrm{XX}$, o mais significativo desses estudos teóricos para a área veio de Paul Natorp. Ao falar desse processo histórico de surgimento da Pedagogia Social, Érico Machado (2013) destaca os processos sociais e educacionais específicos do final do século XIX e início do XX. Ressaltando os contextos de Alemanha e Espanha, Machado (2013) defende que a educação se adapta às condiçôes históricas desses países que no século XIX estabeleceram seus sistemas nacionais. Dessa maneira, a Alemanha é considerada berço da Pedagogia Social, tanto relativo à elaboração das terminologias e sua fundamentação, como também em sua organização e reconhecimento social.

Em outros países, esses estudos também são comuns desde o século passado, mesmo sem a utilização desse termo. No caso do Brasil, Paulo Freire, com suas contribuiçóes no campo da Educação Popular, a partir da segunda metade do século passado, passou a ser visto como um dos grandes pioneiros dessa forma de desenvolver práticas socioeducativas, sendo, ainda hoje, referência para a área (cf. FERREIRA, 2018). Sobre a fundamentação da PS em nosso país:

É importante considerar que no Brasil, a Pedagogia Social é uma área recente, as publicaçóes e discussóes da área estão sendo formuladas cada vez mais em diferentes lugares, com diferentes enfoques (...) o que marca o início da estruturação e fundamentação da área da Pedagogia Social no Brasil, sua 
busca pela legalidade e institucionalização perante as leis brasileiras, pode ser considerado a realização, em 2006 e em 2008, dos I e o II Congressos Internacionais de Pedagogia Social, realizados na Faculdade de Educação da Universidade de São Paulo, sob coordenação do Professor Roberto da Silva. (MACHADO, 2010, p. 3).

Em linhas gerais, a Pedagogia Social no Brasil toma um ar de fundamentação teórica para a atuaçáo prática do educador social, sendo

[...] concebida como uma ciência que pertence ao rol das Ciências da Educação, uma ciência sensível à dimensão da sociabilidade humana, ou seja, que se ocupa particularmente da educaçáo social de indivíduos historicamente situados. Uma educação que ocorre de modo particular lá onde as agências formais de educaçáo não conseguem chegar; nas relaçóes de ajuda a pessoas em dificuldade, especialmente crianças, adolescentes e jovens que sofrem pela escassa atenção às suas necessidades fundamentais. (CALIMAN, 2011, p. 486).

Nessa perspectiva, a educação náo escolar pode encontrar como local de atuação instituições como as associaçóes, clubes, projetos sociais, organizaçóes não governamentais, instituiçôes religiosas, entre outros tantos locais. Algumas características básicas, que "unem" essas práticas/instituiçôes socioeducativas são: atividades de cuidado e ajuda; respostas às demandas específicas de determinados setores mais vulneráveis da sociedade; utilização de trabalho voluntário. Quanto ao último ponto, vale destacar o espaço cada vez maior que é encontrado pelo voluntariado nessas instituiçōes, sobretudo, inspirados por motivaçôes ideológicas, políticas, humanitárias, religiosas (como no caso da presente investigaçáo), entre outras (CALIMAN, 2011).

Entre os locais de atuação dessas práticas socioeducativas - e, consequentemente, área de investigação da Pedagogia Social - estão as ruas e a população em situação de rua. Esse, um espaço configurado pelo caráter de incerteza e, sobretudo, pela necessidade de transformação social: "A rua configura-se como um espaço plural, coletivo, do inesperado. Pensar no espaço da rua sem essa mobilidade característica é pensar, também, em uma educação ancorada (...) na qual não se projeta a necessidade de transformação social" (LIBERALESSO, 2008, p. 121). Portanto, dados os significados táo específicos do trabalho socioeducativo com a população em situação de rua, também novos propósitos e metodologias devem ser pensados, respeitando as condiçóes e demandas desse educando. Destarte, tais questóes fazem parte de uma subárea específica da Pedagogia Social, a Pedagogia Social de Rua, que, segundo Graciani (1999), pode ser definida como:

[...] um atendimento inicial altamente intensivo e específico aos meninos(as) degradados física, mental e moralmente pela vida nas ruas, que apoie a emancipação cidadã pela criação de vínculos que facilitem o resgate da autoestima, da autovalorização e da autoconfiança, condiçóes precípuas para a saída processual das ruas. É isso que denominamos Pedagogia Social de Rua. (GRACIANI, 1999, p. 193). 
É com base nesses princípios da Pedagogia Social (de Rua) que entendemos a relevância do pensamento de autores como Xesús Jares e Isabel Baptista para a área. Por meio de suas teorias, visamos fortalecer práticas (socio)educativas que busquem um desenvolvimento cidadão ao educando-assistido, por meio de um processo que valorize os vínculos entre educador e educando, destacando as potencialidades afetivas e de acolhimento presentes nas práticas educacionais. É o que será mais bem desenvolvido no tópico a seguir.

\section{CONVIVER REQUER HOSPITALIDADE OU HOSPEDAR REQUER CONVIVENNCIA?}

Não é possível pensar em educação sem pensar em convivência; da mesma forma, não podemos pensar em um convívio rico em trocas de saberes e permeado por valores democráticos sem considerar uma relaçáo de alteridade com o outro. Portanto, podemos resumir tais apontamentos numa máxima: educar requer convivência e conviver requer hospitalidade. ${ }^{7} \mathrm{E}$ isso se apresenta imprescindível também para as práticas socioeducativas realizados com pessoas em situaçáo de rua. Como Graciani (1999) pontua, "A Pedagogia Social de rua não é só um processo lógico, intelectual. É também profundamente afetivo e social; daí, a importância de o Educador Social de Rua ser um arguto observador e percebedor atento do educando nos momentos da ação educativa" (GRACIANI, 1999, p. 207).

Nesse ponto, justamente, devemos situar que afetividade e socialização não são apenas modos de agir ou sensos comuns vazios de sentido; partem de uma formação para educadores sociais que abarque tais temas. ${ }^{8}$ Graciani (1999) destaca que "é fundamental para o Educador Social de rua buscar o aprofundamento do próprio referencial teórico atual, fazendo leitura do mundo e dos textos, como diz Paulo Freire" (1999, p. 205). É exatamente o mesmo Freire, patrono da Educação brasileira, que serviu como grande pioneiro teórico das práticas socioeducativas por tanto tempo. Reconhecendo o legado de Freire, mas, ao mesmo tempo, entendendo a necessidade de reorganizar antigos conceitos pedagógicos e pensar em "novas pedagogias" que possam produzir novos sentidos à prática educativa, introduzimos em nosso grupo os estudos das Pedagogias da Convivência e da Hospitalidade. ${ }^{9}$

7 Tais relaçôes entre convivência e hospitalidade na Educação foram mais bem desenvolvidas em nosso texto "CONVIVER REQUER HOSPITALIDADE: pensando modelos de práticas socioeducativas a partir dos diálogos entre as Pedagogias da Hospitalidade e da Convivencia". (PEREIRA; LOPES, 2020).

8 Nesse sentido, nosso próprio grupo (Fora da Sala de Aula da UERJ/FFP) vem realizando uma forte ação de formaçáo gratuita para Educadores Sociais em temas de convivência e hospitalidade (baseados nas Pedagogias de Jares e Baptista) nos últimos anos, realizando cursos de atualização a distância, já tendo certificado centenas de educadores sociais e escolares de todo país.

9 Como melhor trabalhado no texto "A autonomia, a convivência e a hospitalidade como formas de construção de práticas socioeducativas na Educação Integral e $(m)$ Tempo Integral." (FERREIRA; SIRINO; MOTA, 2018). 
Mas o que é a Pedagogia da Convivência (PC) de Jares (2008)? Como podemos ver em Ferreira (2018, p. 40), "a Pedagogia da Convivência é uma reflexão específica da Pedagogia Social sobre o reconhecimento da importância das relaçóes sociais originadas pelos indivíduos nos grupos sociais como potencializadoras de ensino-aprendizagem social". Dessa forma, a Pedagogia da Convivência nos oferece como aporte para o trabalho socioeducativo elementos a serem levados em consideração pelo educador ao elaborar suas práticas didáticas para com as camadas empobrecidas. São elementos essenciais: o respeito; o diálogo; a solidariedade; nâo violência; o laicismo; o perdão; a dinâmica de cultura; a ternura; a diversidade e a felicidade (JARES, 2008). Como lembra Ferreira: "os educadores sociais que assumirem a Pedagogia da Convivência como fundamento de sua prática socioeducacional se comprometem com uma postura específica diante do campo de aprendizagem social" (FERREIRA, 2018, p. 42). Essa postura, para Jares (2008), pressupóe os Direitos Humanos como o marco regulador da convivência. Sendo assim, a ideia central se dá pela "dignidade, inerente a todo ser humano" (JARES, 2008, p. 29).

A convivência da pedagogia de Jares (2008), não possui o mesmo sentido geralmente apontado pelo senso comum, de "estar próximo do outro". Conviver não é um imperativo único, universal, sendo existente em diversos modelos que variam a partir de valores (pessoais e sociais distintos), formas de organização, sistemas socioeconômicos e culturais, normas de enfrentamento ao conflito, entre tantos outros marcos que acometem sua configuração (JARES, 2008). À vista disso, existem diferentes códigos valorativos de convivência e diversos fatores que influenciam em nossa forma de conviver; consequentemente, sabe-se que existe também a possibilidade da aprendizagem de diferentes formas de conviver. Nesse caso, a pergunta que fica é: que convivência nós aspiramos viver e para qual queremos educar? Para Jares (2008), esse modelo seria pautado em uma convivência democrática, no Estado de Direito assentado na justiça social, cumprindo com os Direitos Humanos de maneira universal.

Para além da convivência, fazem parte do tripé da Pedagogia da Convivência de Jares, ainda, a Educação para a Paz e o conflito (SILVA, 2019). O educador cataláo concebe a Educação para a Paz como um processo educativo, contínuo e permanente que, por meio da aplicação de métodos problematizantes, busca o desenvolvimento de uma cultura da paz, que ajude as pessoas no entendimento crítico da realidade (desigual, violenta, complexa e conflituosa), para poder ter uma atitude e uma ação diante dela (JARES, 2007). Desse jeito, a paz à qual Jares se refere não faz oposição à guerra, mas às violências, em todas as suas esferas. ${ }^{10}$ Buscar

10 Com base na tipologia da violência elaborada pelo sociólogo Johan Galtung, Jares (2002; 2007), o qual considera a existência da violência em três esferas: a direta, compreendida como a agressão física direta, o ataque contra a vida e o corpo do outro; a estrutural, referente às desigualdades presentes em determinada estrutura social, sinônimo de injustiça social; e a cultural, representado por aspectos da cultura (materializados na religião, na ideologia, na linguagem, na arte, na ciência etc.) que pode ser utilizada para legitimar a violência direta ou estrutural. 
um projeto educacional para paz tem o sentido de "não aceitação dessas situaçóes de violência como naturais, buscando por meio da educação a consciência de sua existência" e tendo por objetivo a "eliminação de desigualdades, repressóes, abusos contra os direitos humanos de uma maneira geral" (LOPES, 2019, p. 67).

Em relação ao conflito, outro pilar formador da PC, Xesús Jares o concebe a partir de uma perspectiva positiva, ou seja, para o educador cataláo, o conflito é "natural e inevitável na existência humana, como atribui-se a ele, em segundo lugar, uma característica realmente antitética à concepção tradicional: sua necessidade" (JARES, 2002, p. 134). O conflito não deve ser pensado (na vida ou na educaçáo) como algo a ser eliminado, como intrinsecamente negativo; sendo mediado da maneira adequada, por uma concepçáo de não violência, ele pode apresentar grandes potencialidades, servindo para a construção de novos saberes e de uma convivência mais democrática.

Já o que denominamos de Pedagogia da Hospitalidade (PH), a partir da obra de Isabel Baptista, o conflito não é excludente a isso, mas, na nossa visão, complementar. No entanto, partindo do pressuposto da existência de diferentes modelos de convivência, devemos pontuar, antes de tudo, que a $\mathrm{PH}$ estabelece importantes diferenças, sobretudo em seus pressupostos iniciais, se comparada ao modelo de Jares. Fazendo um exercício de construção dos marcos éticos e valorativos da convivência a partir da obra de Baptista, podemos dizer que esse modelo educativo parte, em grande medida, da alteridade existente na relaçáo entre o "eu" e o "outro" para elaborar suas práticas. Dessa maneira, essa Pedagogia coloca a alteridade na centralidade do convívio, considerando a indissociabilidade do eu com o outro, de forma que a convivência com o que é diferente gere também uma interdependência, onde "nós somos, reconhecemo-nos e nos potencializamos a partir da coexistência com o outro" (PEREIRA; LOPES, 2020, p. 74).

Em síntese, podemos definir a $\mathrm{PH}$ como um modelo educacional (escolar ou náo escolar) que parte do plano de uma ética profissional própria para os educadores nos (difíceis) tempos atuais marcada por um marco de convivência baseado na alteridade com o outro, e recebendo esse como hóspede. O hóspede, no sentido de Baptista, deve ser recebido em nosso espaço com uma abertura verdadeira aceitando o outro como ele é, oferecendo o que temos de melhor, sem sentimentos de medo -, permeada por práticas de acolhimento, alteridade, cortesia e sensibilidade (BAPTISTA, 2005).

Seja em que circunstância for tratar alguém como hóspede significa que aceitamos recebê-lo nos nossos domínios, na nossa casa, colocando à sua disposição o melhor do que somos e do que possuímos sem que isso represente uma perda de poder sobre as nossas coisas (...). Por outro lado, o nosso canto fica mais rico pela novidade que, entretanto o habitou. (BAPTISTA, 2005, p. 49).

Considerando tais objetivos e características da PH, Isabel Baptista (2005), definiu três princípios para guiar todas as açóes educativas baseadas em sua pedagogia: 1) o reconhecimento da perfectibilidade do ser humano; 2) a crença 
incondicional na possibilidade de educabilidade; 3) o reconhecimento ético do "negativo da educabilidade" (BAPTISTA, 2005, p. 75). Essas duas primeiras, como a própria autora destaca, sáo intimamente ligadas e naturalmente indissociáveis. $\mathrm{O}$ reconhecimento da perfectibilidade humana parte da ideia do ser humano como um ser do inacabamento, que, sendo assim, vive uma existência permanentemente mutável, podendo alcançar o aperfeiçoamento e um desenvolvimento positivo, "é, sobretudo, uma posição de esperança frente às mazelas do mundo e da vida; não uma esperança que 'cegue' que os problemas existem (...), mas uma esperança que tenha como norte a clareza da possibilidade de intervir para que as coisas melhorem". (LOPES, 2020, p. 106). Consequentemente, se o ser humano é um projeto, reconhecemos em todos nós uma natureza educável, sendo a educaçáo uma das ferramentas que pode atribuir sentido a esse processo de desenvolvimento. Como pontua Baptista: "A profissão de educador perderia todo o sentido sem a crença na educabilidade das pessoas, de todas as pessoas" (2005, p. 76). Por fim, o negativo da educabilidade é onde se tem o reconhecimento que a prática educativa nem sempre terá seus objetivos alcançados, mas que, ainda assim, deve-se acreditar, sem que isso gere uma culpabilização ou angústia no educador.

Por fim, outro conceito que é de grande relevância para nosso artigo é o de lugares de hospitalidade (BAPTISTA, 2008). Conforme a educadora portuguesa, lugares de hospitalidade são lugares de urbanidade, cortesia cívica, responsabilidade e bondade, convidativos à entrada do outro, ofertando acolhimento, refúgio. Para a autora, "falar de hospitalidade significa, justamente, ter em conta as múltiplas implicações presentes nessa dupla relação humana: a relação com o lugar e a relação com o outro" (BAPTISTA, 2008, p. 6). Mas, se tais lugares possuem um espírito que os guarda, um "senhor do lugar" que abre ou dispôe seu espaço para o outro adentrar, o que falar das ruas? Diferente de ser um lugar de ninguém, a rua é um espaço de todos e, mesmo possuindo um caráter transitório, sendo um lugar do imprevisto e do risco, não deixa de ser um local de potencialidades. Assim, mesmo "perante um lugar que sendo de trânsito não deixa de ser um lugar de alteridade, por mais circunstancial e efémera que possa ser a experiência de hospitalidade ou, neste caso, de transhospitalidade" (BAPTISTA, 2008, p. 11).

Consonante a isso, podemos trazer ainda a contribuição de Lúcio Grinover (2015), para melhor entender a viabilidade e as potencialidades existentes entre a hospitalidade e as ruas. Como destacou o autor: "não é possível falar de espaços hospitaleiros, nem de lugares hospitaleiros, mas de 'usos e ocupaçóes hospitaleiras do espaço', o que nos dá a característica da hospitalidade no espaço construído" (GRINOVER, 2015, p. 166). Esse pensamento tem como embasamento a nova constituiçáo urbana, agora sem uma estrutura táo rígida, com uma crise dos valores racionais de sua construção, mas, ao mesmo tempo, ainda como um lugar de construçáo de experiências, que nos atravessa e nos modifica. E são esses atravessamentos que podem fazer com que esses espaços se tornem locais de hospitalidade.

Portanto, mesmo que com diferenças pontuais, cabe pensarmos nas Pedagogias da Convivência e da Hospitalidade como complementares; passando por caminhos 
distintos, mas sempre paralelos. Ainda que Jares e Baptista pouco tenham dialogado diretamente em suas obras, ${ }^{11}$ é evidente que suas teorias possam gerar diversas reflexóes comuns. Como podemos perceber, ambos modelos pedagógicos propostos pela PC e pela PH "possuem diversos aspectos em acordo, tais como, a defesa de uma convivência democrática e o reconhecimento dos Direitos Humanos como chave para o compromisso ético da educação nos tempos atuais", funcionando dessa forma, como "práticas possíveis contra a descrença, a desesperança e as mais diversas violências presentes no mundo contemporâneo". (PEREIRA; LOPES, 2020, p. 68). Tendo ambos destacado os desafios e dificuldades próprias que a sociedade global do século XXI possui, seus modelos pedagógicos partem desses mesmos problemas por um objetivo em comum:

[...] uma educação que seja geradora de esperança de um futuro melhor, de construçáo de cidadãos mais ativos e engajados em fazer a diferença frente às injustiças e violências de seu tempo e espaço. Para isso, ambos modelos pedagógicos têm como foco o relacionar-se com o outro; o outro que é dotado de valores e culturas próprias, que deve receber todo o respeito e a abertura ao diálogo e a convivência. (PEREIRA; LOPES, 2020, p. 68).

Situando tais encontros (e desencontros) dessas pedagogias, podemos ver suas potencialidades de uso nas práticas socioeducativas com populaçóes em situação de rua. Da necessidade do educar vir junto com o conviver, e do conviver trazer consigo valores de hospitalidade e acolhimento para esse outro que se encontra vulnerável. Tais vulnerabilidades, cabe destacar, que fazem parte das inúmeras violências cotidianas sofridas por esse outro que habita nas ruas. E que situaçáo mais propícia teria para se comprometer a uma Educação para a Paz se não com esses grupos? A partir do uso dessas ferramentas, finalmente, buscamos propiciar

11 Um raro momento de diálogo das obras pode ser encontrado no texto "Ética, Deontologia e Avaliação do desempenho docente" (BAPTISTA, 2011), onde a autora cita a obra de Jares. Nesse texto, podemos notar como a própria Baptista - indiretamente - corrobora a importância do "conviver requer hospitalidade"; para ela, quando se está de acordo com um estatuto éticodeontológico, a avaliação do desempenho docente favorece os processos de construção social no ambiente educacional, valorizando uma convivência democrática e socialização positiva. Assim, a partir dos pressupostos éticos e deontológicos de Baptista (para práticas educativas, avaliaçóes etc.), tal como a Pedagogia da Hospitalidade como um todo, ficamos mais perto de pôr em prática a Pedagogia da Convivência defendida por Jares (cf. BAPTISTA, 2011, p. 50). 
a criaçáo de lugares de hospitalidade e uma formaçáo cidadã ${ }^{12}$ para esse outro táo invisibilizado por tantos.

\section{ANÁlISE DAS PRÁTICAS COM A POPULAÇÃO EM SITUAÇÃO DE RUA}

Considerando toda contextualização e referenciais teóricos apresentados até aqui, focaremos nosso trabalho na análise das práticas realizadas pela Missão Católica Discípulos de Assis com as pessoas em situação de rua na cidade de NiteróiRJ. Nosso principal objetivo aqui é encontrar situaçóes onde foram usados (ou poderiam ter sido usados) elementos presentes nas Pedagogias da Convivência e da Hospitalidade, tais como as que apresentamos anteriormente.

Para isso, fizemos um recorte do diário de campo utilizando apenas trechos do noema, visto que este "nos permite uma visáo mais imparcial do objeto descrito, oferecendo à análise um material sem tantas impressóes pessoais do observador embora o próprio ato de observar um campo e descrevê-lo carregue marcas pessoais" (SILVA, 2020, p. 197). Como se sabe, a descrição do campo no noema "se faz da forma mais 'fria' possível, tentando ser predominantemente mais descritivo. Não se faz juízos de valor quanto às atitudes ocorridas (...) Não se especula o porquê de cada um dos agentes envolvidos na ação agir de determinada forma”. (LOPES; FERREIRA, 2019, p. 226).

Importante ressaltar que terão fragmentos de diversos noemas relativos a uma só visita à Missáo. Isso se dá devido aos lugares que os agentes passavam e paravam para realizar a prática socioeducativa, visto a atividade nos fins de semanas se caracterizar por esses educadores caminharem nas ruas da cidade indo ao encontro dos educandos. Neste artigo, analisaremos cinco de seis açóes observadas. Além disso, a intenção não é julgar ou criticar as práticas dos agentes, mas gerar uma reflexão sobre as demandas das populaçôes em situação de rua e ratificar a importância deste tipo de trabalho para as pessoas socialmente vulnerabilizadas.

12 Esse ponto, sem dúvida, é um dos mais importantes aqui. Como Paiva (2015, p. 90) destaca, o trabalho do educador social de rua surge ao longo de todo um processo histórico de exclusão e abandono de crianças e adolescentes que vêm desde o Brasil Colônia; dessa forma, o trabalho do educador social chega às ruas não para legitimar que ali é o lugar das crianças (e adolescentes, adultos, idosos...), mas para realizar a concretizaçáo de direitos inalienáveis que esses têm, tal como a educaçáo. Como a autora destaca: "Como qualquer processo educativo libertador, a educação de rua pressupóe um trabalho de construção de cidadania” (PAIVA, 2015, p. 92). Também Graciani (1999, p. 192), ao tecer um eixo delineador das possibilidades do educador de rua, destaca o papel do educador social de usar uma pedagogia adequada para resgatar a cidadania e identidade desse educando-assistido. Da mesma maneira, considera que um dos principais objetivos da Pedagogia Social de Rua é "o de estimular as crianças e adolescentes de rua a discutirem, entenderem e aceitarem de forma digna, as regras e os limites necessários ao exercício da cidadania" (GRACIANI, 1999, p. 196). Por fim, vale salientar que essa busca pela cidadania como finalidade educativa em nada contradiz as Pedagogias da Convivência e da Hospitalidade, visto que ambos os autores destacam sua importância (em maior ou menor incidência) em suas obras (cf. BAPTISTA, 2005; JARES, 2008). 


\section{Noema 1 - 05 de agosto de 2018}

Neste dia, os agentes 1,13 2 e 3, fixos do grupo, encontraram o Agente 4, que estava visitando o grupo, no Terminal Rodoviário Presidente João Goulart. Eles fizeram a oração inicial e saíram em missão em direção à Praça Juscelino Kubitschek. ${ }^{14}$ Chegando à Praça, localizada próxima à Estação Praça Arariboia - terminal hidroviário, ao shopping center e ao Terminal Rodoviário, estando ela com pouca movimentação e escura, os agentes encontram sob a segunda cobertura da praça, próximos à escadaria da mesma cobertura que leva ao estacionamento da mesma, os assistidos 1, 2 3, 4 e 5. (...) Ao lado deles havia mochilas cheias de objetos não reconhecíveis, lençóis e edredons. (...) Os voluntários cumprimentaram os assistidos e se dividiram. Os agentes 3 e 4 sentaram no chão e ficaram conversando com os assistidos 4 e 5 ; e os agentes 1 e 2 se sentaram com os assistidos 1 e 2, juntos ao Assistido 3 que estava sobre uma mureta. (...)

Agente 1: E aí, cabra safado, como tu tá? - disse ao se sentar junto a eles.

Agente 2: $\mathrm{Oi}$, gente. Boa noite. Como vocês estão?

Assistida 2: Oi, boa noite, disse sorrindo do modo que o Agente 1 se dirigiu ao Assistido 1.

Assistido 1: Vou bem (sorriu), e tu?

Agentes 1 e 2: Vou bem.

Agente 1: E aííííí?, disse ao Assistido 3.

Assistido 3: Oi, oi, oi. Vai bem? Vai bem?

Agente 1: Sim, e tu?

O Assistido 3 ficou sentado na mureta.

Os assistidos 1, 2 e 3 receberam o lanche e começaram a comer. Ao desembrulhar o pão, que estava embrulhado com guardanapo, a Assistida 2, parceira afetiva do Assistido 1, joga o papel no chão da praça, um pouco à frente de onde eles estavam sentados.

Agente 1: Jogando lixo no chão?

O Assistido 3, antes do Agente 1 falar, já estava indo limpar.

Assistida 2: A gente limpa. Cada um varre um dia. Hoje é dia dele.

O local ao redor de onde eles estavam sentados estava limpo de sujeiras postas propositalmente, só se encontrava algumas folhas das árvores que tem no local.

Para além da ajuda nas demandas materiais, há, entre os agentes, o interesse de saber como os assistidos se encontram. Nota-se que os agentes, ao encontrarem os assistidos, não apenas os cumprimentam, como também sentam ao lado deles para conversarem, propiciando um espaço de convivência, onde a ternura, o respeito e a solidariedade, conteúdos essenciais para tal prática (JARES, 2008), tornam-se evidentes, assegurando o acolhimento. Tal noema mostra que a acolhida e abertura à alteridade, por parte dos educadores, gerou um lugar de hospitalidade, onde os assistidos não apenas respondem aos agentes, mas também perguntam como eles se encontram, contribuindo, assim, para um diálogo sem reservas.

13 Para não expor a identidade dos agentes e dos assistidos presentes nos relatos, identificaremos esses por meio de numerais ao invés dos nomes reais.

14 Também conhecida como "praça branca". Fica numa distância aproximada de 1,6km do Terminal Rodoviário mencionado anteriormente. 
Dentro do noema analisado, entre tantos gestos por parte dos agentes e dos assistidos que apontam para a existência do acolhimento e da abertura para o "outro", a coloquialidade usada pelo "Agente 1" ao se referir ao "Assistido 1" como "cabra safado", afirma uma proximidade e uma intimidade entre ambos, garantindo, assim, um diálogo mais fluido e espontâneo. A continuidade do diálogo entre os agentes e os assistidos evidencia que o contato entre eles náo se resumiu a uma superficialidade, mas proporcionou uma verdadeira abertura, onde a alteridade não foi vista como um obstáculo para o acolhimento e para a prática de uma convivência que é hospitaleira. As primeiras linhas mostram que há tanto por parte dos agentes quanto por parte dos assistidos o desejo de falar, mas também o de ouvir, o que resulta diretamente na partilha de vivências e na criação de vínculos sem desconfiança, colocando em prática, uma convivência que, de acordo com Baptista (2005), não é confundida com o quietismo ou com a tolerância passiva, mas que é revelada na atençáo e no cuidado, tendo sempre o "outro" como sujeito ativo dentro deste encontro.

No noema a seguir, vê-se que o "Agente 1", com a intençáo de dar continuidade ao diálogo, traz à memória lembranças relacionadas ao "Assistido 1", reafirmando que dentro desse encontro, a partilha de memórias e a abertura são reais:

Agente 1: Menino, e quando ele estava com aquele cabelo pintado horroroso? - disse se referindo ao cabelo do Assistido 1.

Assistida 2: Tava mesmo.

Assistido 3: É... É... Pintado? Pintado?

Assistido 1: É... ficou feio mesmo, disse sorrindo.

Agente 1: Vocês estavam começando a ficar juntos, né?!

Assistidos 1 e 2: É... É...

Agente 1: Eu lembro. Ela tava bolada.

Assistido 1: É, bolada, disse confirmando.

Agente 2 sorri.

Agente 1: E depois cortou. Ficou amarelo baixinho.

Assistidos 1 e 2 riem confirmando com a cabeça.

Agente 1: Depois saiu.

Assistido 2: E. Fui no salão ali e cortei.

Assistido 3: Ali, no saláo? Ali?!, disse "acenando com a cabeça" mostrando a direção.

Assistido 1: É. É aquele negócio de menor aprendiz. Eles cortaram.

Agente 2: Aham.

Assistido 1: Eles tão testando. Aí eles cortam, né?!

Agente 2: Ah! É?! Legal. Aqui, é mais tranquilo, né?!

Assistida 2: É, mas é perigoso.

Assistido 1: É.

Agente 1: Não parece.

Assistida 2: É... Agora. Mas depois que vocês vão embora. Hum.

Assistido 1: É...

Agente 1: As pessoas nem passam muito por aqui, né?! Muitos dizem que aqui é perigoso, porque veem vocês como ladróes... Só porque estão assim.

Assistida 2: Não, mas tem gente.

Assistido 1: Tem.

Agente 1: Mas tô falando do povo que fala de vocês. 
Assistido 1: É. Não, porque, assim, só porque a gente tá aqui, eles acham que a gente vai roubar.

Agente 1: É...

A lembrança trazida pelo "Agente 1" mostra que há um vínculo entre os sujeitos participantes desse diálogo, vínculo constituído, através de encontros e conversas, o que firma a existência de uma cortesia que náo é apenas convencional, mas que acontece com uma real autenticidade, proporcionando a construção de laços de proximidades.

No mais, não se atende somente à relação de diálogo entre os agentes e os assistidos, o recorte do noema mostra que, ao ser perguntado sobre a tranquilidade do lugar, o "Assistido 1" ao responder, não somente explica que é um lugar perigoso, mas também faz uma diferenciação entre as pessoas que estão em situação de rua e as pessoas que estão em situação de rua e assaltam. Ao fazer essa diferenciação, ele fala sobre o preconceito sofrido, quando se acha que o fato de viverem nas ruas faz com que se tornem automaticamente assaltantes. Evidentemente, o desabafo feito pelo "Assistido 1" aponta, não somente para a desumanização que é feita com os assistidos, mas também para a questão sobre a concepção que temos a respeito do outro, na alteridade. A falta de uma abertura ao que é distinto, a partir de uma visão negativa sobre a alteridade, coloca o outro sempre como uma ameaça. Isabel Baptista assegura:

A forma que equacionamos a relação com os outros depende muito da concepçáo de "outro" que tivermos em referência. O outro é uma ameaça, um inimigo em potencial, alguém que simplesmente toleramos, ou pelo contrário, é alguém que só por efeito da sua entrada na esfera da nossa mesmidade, representa uma mais-valia, uma ocasião de enriquecimento pessoal? (BAPTISTA, 2005, p. 45).

Apesar do desabafo feito pelo "Assistido 1", o recorte do noema a seguir evidencia que a proximidade e a convivência entre os agentes e os assistidos é assegurada no acolhimento, na ternura e na solidariedade (JARES, 2008):

Os agentes se despediram e deram um abraço em cada um deles. Depois foram se despedir dos assistidos 4 e 5, este último, na despedida, falou que dia 17 de agosto seria o seu aniversário. O Agente 1 falou para ele que eles levariam um bolo no dia 19 para comemorar o seu aniversário.

Agente 1: A gente vai trazer um bolo para o senhor.

Assistido 5: Tá bom.

Agente 1: É para estar aqui, viu?! Senão tiver... hum..., disse sorrindo.

Agente 2: É para estar aqui mesmo.

Agente 1: É para estar mesmo, porque se não tiver, vou brigar com o senhor, viu?!

Os assistidos 4 e 5 sorriram juntos.

Durante todo esse contado, carros iam e vinham, poucas pessoas passavam, e das que passavam, apenas algumas olhavam para o local deles. Os agentes se despediram e continuaram o trajeto carregando nas máos as garrafas de suco dentro de sacolas plásticas e puxando o carrinho de compra com páes. 
Dentro de tantos afetos e acolhidas, perceptíveis no diálogo, a ação do "Assistido 5", de compartilhar com os agentes que o seu aniversário estava chegando, demonstra que há um grau de amizade e de confiabilidade nos agentes que permite falar de algo particular em relação à sua vida. Entendendo que a verdadeira prática da hospitalidade náo pode se desenvolver em um espaço de frieza e de indiferença (PEREIRA; LOPES, 2020), a sensibilidade por parte dos agentes, de entenderem a importância do que foi compartilhado pelo assistido e de prometerem que iriam levar um bolo, para comemorar tal data, mostra que há um compromisso social e afetivo, que perpassa pelo cuidado e pela valorização do outro com suas partilhas de vivências e memórias. Cabe ressaltar que o diálogo presente entre os agentes e os assistidos, de acordo com Jares (2008), na prática da convivência, é essencial, visto que, segundo o autor, o rompimento desse, inviabiliza a possibilidade de convivência e também a resolução de conflitos.

\section{Noema 2 - 19 de agosto de 2018}

Os agentes 1 e 2, fixos do grupo, e a Agente 5, que estava visitando a Missáa, encontraram-se no Terminal Rodoviário, fizeram a oração inicial e foram em direção à Praça Juscelino Kubitschek com os sanduíches, as garrafas de sucos e refrigerantes e o bolo do Assistido 5. Neste dia, a Agente 2 náo compareceu à missão, mas fez o bolo de chocolate e entregou aos agentes 1 e 3, que chegaram com ele ao Terminal Rodoviário e comentaram que a Agente 2 não poderia comparecer, mas que havia feito o bolo. Chegando à Praça, eles encontraram os assistidos 1, 2, 3, 4 e 5 .

Agente 1: Ooooooiiii... Chegamos.

Todos se abraçaram e se cumprimentaram.

Agente 1: Aqui, trouxemos o seu bolo, disse segurando o bolo.

Assistido 5: Muito obrigado! Deus abençoe! Muito obrigado mesmo.

Agente 1: Vamos cantar parabéns?!

Assistido 5: Vamos, sim! Chama o pessoal aí. (Ele falava dos assistidos 1, 2 e 3).

Cantaram "parabéns" e comeram o bolo acompanhado pelas bebidas que os agentes tinham levado. Ficaram rindo, brincando; e o Assistido 5 sempre agradecendo...

Após a confraternização, os agentes se despediram deixando o que ainda havia de bolo na bandeja de plástico própria para bolo e um refrigerante.

Agente 1: Vamos deixar aqui com o senhor, tá?!

Assistido 5: Pode deixar, a gente come mais tarde e, dependendo, até amanhã de manhá.

Agente 1: Tá bom. Tchau, despede-se abraçando.

Os agentes se abraçaram e seguiram em direção à Cantareira, ${ }^{15}$ mas voltaram da Praça mesmo antes de chegarem ao local que iam. Ao passarem ao lado deles de novo, os agentes deram "tchau" sorrindo para eles; e o Assistido 5 respondeu dando "tchau", agradecendo pelo bolo e desejando que Deus os abençoasse.

15 Popularmente conhecida como "Praça da Cantareira", com distância aproximada de $800 \mathrm{~m}$ da Praça Juscelino Kubitschek. 
Mesmo não indo dessa vez, a "Agente 2" fez o bolo que havia prometido e deu para que os outros agentes levassem. Isso demonstra um compromisso do agente, dentro da ação de hospitalidade, não somente na teoria, mas também na prática. O ato do "Assistido 5", de chamar todos os outros assistidos que ali estavam para partilharem daquela comemoração, reafirma a possibilidade de pensar a prática da hospitalidade em todos os espaços da sociabilidade humana. Baptista afirma:

É nessa linha de sentido que importa evidenciar as práticas de hospitalidade em todos os espaços humanos, sobretudo quando os investimos de uma responsabilidade pedagógica intencionalmente acrescida, como acontece com as instituiçôes socioeducativas. Mas a exigência de que falamos não se circunscreve a este tipo de instituições, ela estende-se a todos os lugares da vida pública, inclusive os lugares de trânsito como estaçôes de comboio, aeroportos, hotéis, cafés, centros comerciais, parques, praças e todos os outros espaços de sociabilidade humana (2005, p. 49).

No mais, o afeto e a acolhida por parte dos agentes e dos assistidos afirma que a abertura à alteridade aconteceu de maneira profunda, onde as experiências de comemoraçóes e vivências do "Assistido 5" não foram individualizadas, mas partilhada com os outros.

\section{Noema 3 - 03 de setembro de 2018}

Os agentes 1, 2, 3 e 5 se encontraram atrás do Terminal Rodoviário às $18 \mathrm{~h}$ com carrinhos de compras cheio de pães com mortadela e alguns litros de suco para irem em missão. Ao esperarem algumas pessoas e elas não terem chegado, começaram a oração inicial pedindo pelo bom êxito da missão, visto o horário. Ao terminarem a oração e irem em direção à saída do Terminal, chegando lá, os agentes se dividem para adiantar a missão, porque a Agente 5 teria que sair mais cedo naquela noite e não queriam ficar na rua em missão com um número menor. Entáo, seguem os agentes 2 e 3 para a frente da Estação Praça Arariboia ${ }^{16}$ e os agentes 1 e 5 para a rua São João, especificadamente no Jardim São João. ${ }^{17}$

Os agentes 1 e 5 foram conversando sobre diversos assuntos até chegarem aos assistidos 6 e 7. Os agentes abordam o Assistido 6 com o Agente 1 falando alto e sorrindo chamando-o pelo nome. Vendo que eram os agentes pastorais, o Assistido 6 levanta de cima de uma tábua grande coberta com lençóis que está sobre alguma espécie de suporte como se fossem cavaletes e responde "Oi!" sorrindo tímido.

Agente 5: Oiii.

Assistido 6: Oi...

Deram o lanche a ele enquanto conversavam perguntando como ele estava. Ele logo responde que está bem com uma expressão sonolenta, de cansado e de abatido. O Agente 1 olha com expressão de estranheza. Assim, dão "tchau"

16 A Estação Praça Arariboia fica numa distância aproximada de 1,3km do Terminal Rodoviário.

17 Formado por duas Praças, uma delas, onde está situada a Catedral Metropolitana Sáo João Batista e funcionando o comércio popular. Fica numa distância aproximada de $1,3 \mathrm{~km}$ do Terminal Rodoviário. 
para ele e atravessam para o lado da rua, indo até à calçada que a Assistida 7 estava. Na travessia, o Agente 1 comenta com a Agente 5 sobre o Assistido 6: "Ele está diferente. Ele não é tão pra baixo.".

Diferentemente dos outros noemas que foram analisados anteriormente, onde há uma abertura para o diálogo e para a partilha de afetos, no relato acima, deparamo-nos com uma situação que, talvez, não fosse esperada pelos agentes, mas que ainda assim ocorreu. Após o "Agente 1" cumprimentar o "Assistido 6" e perguntar como ele se encontrava, a resposta do "Assistido 6" gera estranheza no "Agente 1". Mas, apesar da estranheza gerada, não há uma insistência por parte dos agentes em continuarem o diálogo, sendo assim, eles partem, mesmo sabendo que o "Assistido 6" estava diferente e que náo era uma pessoa táo desanimada. Apesar da prática da hospitalidade também estar relacionada ao ato de respeitar espaços e silêncios (Baptista, 2005), a não insistência por parte dos agentes, em saber sobre o que se passava com o "Assistido 6", aponta para a ausência de uma acolhida e de uma atenção maior para tal momento. Embora a resposta dada pelo assistido náo fosse a esperada, ainda assim, o conflito causado pela resposta poderia ser mediado, proporcionando não somente um diálogo mais profundo, mas também uma convivência mais democrática, onde o assistido pudesse se sentir mais confortável e acolhido para falar sobre o que se passava com ele, caso houvesse algo. Para além da perspectiva tradicional que se tem sobre o conflito, como sinônimo de violência e de algo negativo, Jares (2002), ao reformular essa concepção tradicional, assume o conflito como algo que ele realmente é: um processo natural, necessário e potencialmente positivo para as pessoas e para os grupos sociais. Sobre isso, ele assegura:

Em primeiro lugar, afirma-se que o conflito é consubstancial e inevitável à existência humana: "o estado natural do homem é conflito" (Mendel, 1975, p. 13). Não se trata, portanto, de negar tal realidade, já que "o conflito existe desde o início" (Muller, 1983, p. 13), mas de oferecer os meios adequados e enfatizar suas estratégias de resolução pacifica e criativa. "Enfrentar o desacordo não equivale a um processo autodestrutivo. $\mathrm{O}$ conflito não é mal em si, embora as pessoas possam responder a ele de forma negativa" (Pallares, 1982, p. 103). Por conseguinte, a chave não está em sua eliminação, mas em sua regulação e resolução de forma justa e não violenta (JARES, 2002, p. 134).

Assim, Jares aponta para a necessidade de métodos que não eliminem o conflito, mas que o regulem, onde, através dele, se possa alcançar resultados positivos.

No recorte do noema a seguir, observa-se que ao encontrarem a "Assistida 7", dormindo e deitada sobre os lençóis dentro de um carrinho, os agentes de maneira cuidadosa a chamam baixinho pelo nome demonstrando uma abordagem cuidadosa:

A Assistida 7 estava com as duas pernas inchadas, uma mais que a outra, e deitada sobre lençóis dentro de um carrinho de reciclagem cheio de papelão e 
algumas garrafinhas plásticas e latinhas de alumínio junto à sua cachorra. Os agentes a abordam falando baixinho e a chamando pelo nome.

A cachorra acorda e levanta meio sonolenta, mas continua dentro do carrinho junto à assistida. Logo em seguida, a assistida acorda sonolenta e começa a conversar com os agentes:

Agente 1: Como você está?

Agente 5 prepara o lanche para ela.

Agente 1: Você quer um lanche?

Assistida 7: Aceito.

Agentes 1 e 5: Aqui, ó, dizem o entregando a ela.

A Assistida o recebe meia cabisbaixa, intercalando o olhar entre o lanche e os agentes.

Assistida 7: Obrigado. E vocês, como estão?

Agentes 1 e 5: A gente tá bem. E você?

Assistida 7: Ah! Tô levando.

O Agente 1 reclama que está cansado enquanto ela come e dá comida para a cachorra.

Agente 1: Aaaaiii... eu não gosto de cachorro, disse sorrindo.

Assistida 7: É minha Pitica.

Agente 1: Aaaai...

Assistida 7: Ooolha..., disse em tom de repreensão. Ela dorme aqui comigo na minha burrinha, continuou.

Agente 5: Liga pra ele não. Ele é um chato...

O Agente 1 ri enquanto a Assistida 7 continua dando comida à cachorra.

Além de todo o cuidado que é evidente na abordagem feita pelos agentes, nota-se o acolhimento que é feito ao dialogarem com a assistida, demonstrando todo o interesse em saber como ela se encontrava. Um dos pontos que também chama atenção no noema analisado é a forma que o "Agente 1" conversa com a assistida, de maneira aberta e sem reservas, falando sobre o seu cansaço e até mesmo emitindo sua opiniáo sobre não gostar de cachorros. Tal ponto evidencia que o afeto e acolhida se fazem presentes dentro do diálogo, onde os agentes e a assistida, além de partilharem gostos e afetos sem medo e sem desconfiança, também respeitam aquilo que é transmitido e que já existia anteriormente com o outro.

Náo dando foco somente à existência de acolhida e afetos dentro desse encontro entre os agentes e a assistida, nota-se que o diálogo ao ser aprofundado concede o espaço para que o agente ofereça uma ajuda no que se refere ao ato de ler:

Agente 1: Você sabe ler?, chamando-a pelo nome.

Assistida 7: Pouco.

Agente 1: Cê queria aprender?

Assistida 7: Queria. Mas é que...

Agente 1: A gente pode te ensinar.

Assistida 7: Meu bem, mas é que...

Agente 1: Aqui, ó, ela é professora de Português, disse tocando na Agente 5.

Assistida 7: Mas é que eu não consigo lembrar bem das coisas. Eu...

Agente 1: Por quê?

Assistida 7: Eu tive um negócio na cabeça, não sei... derrame...

A agente 5 fica olhando fixamente para a assistida 7 .

Agente 1: Entendi. Mas você não consegue lembrar mesmo?

Assistida 7: Assim... Um pouco... Eu consigo... 
Agente 1: Entendo... Então, a gente vai se organizar para ver isso... próxima vez que a gente vier, a gente te dá uma resposta, tá?!

Assistida 7: Tá bom.

Agente 1: Vamos fazer uma oração?

Assistida 2: Vamos, aceita sorrindo.

Eles fazem uma oração espontânea. Os agentes a abraçam e dão um beijo em seu rosto. Ela faz o mesmo com eles. Os agentes atravessam para o outro lado da rua. Olham se tinha mais alguém no final da rua. Decidem não irem até lá e voltam. Despedem-se do Assistido 6 e seguem na rua São João em direção ao Terminal Rodoviário João Goulart para se encontrarem com os agentes 2 e 3, que fizeram outro trajeto.

O recorte do noema analisado traz questóes importantes. Apesar da assistida falar sobre a sua enfermidade e explicar que ela dificulta lembrar de algumas vivências, nota-se que o "Agente 1", ao saber do ocorrido, não coloca essa enfermidade, tão rapidamente, como um obstáculo pedagógico, que pudesse impedir que a "Assistida 7 " aprendesse a ler, mas afirma que iria organizar algo e que, no próximo encontro, eles teriam uma resposta concreta. Outro ponto importante é que o "Agente 1", antes de orar, pergunta à "Assistida 7", se ela aceita. É interessante que a forma que ele faz a pergunta coloca a assistida diretamente no ato da ação, náo como um espectador que assiste ao ato, mas como protagonista que é ativa juntamente com os agentes. $\mathrm{O}$ ato, feito pelos agentes, nos pontos citados acima, demonstra a sensibilidade deles ao entenderem a vulnerabilidade da situação que foi partilhada pela assistida e também aponta para uma relação horizontal, onde nada é imposto ou feito sem a abertura do outro para isso.

\section{Noema 4 - 03 de novembro de 2018}

Os agentes 1 e 3 com pães franceses dentro de três sacolas plásticas foram do Terminal a pé à festinha - organizada pela Missáo Católica Discípulos de Assis e por outros grupos que realizam o mesmo trabalho - para as crianças que moram no Edifício Amaral Peixoto, ${ }^{18}$ na Avenida Ernani do Amaral Peixoto, em Niterói. Eles caminham rapidamente por estarem atrasados por causa do ônibus que havia demorado chegar ao Terminal Rodoviário. Os agentes estavam caminhando rapidamente porque estavam atrasados. Eles iam conversando sobre assuntos particulares deles. Na Estação Praça Arariboia terminal hidroviário - ao lado do semáforo, eles encontram os assistidos 8 e 9 , este último, eles não o chamaram pelo nome por não conhecer, como afirmam entre si. (...) O Agente 1 aponta o Assistido 8 ao Agente 3; e o chamam pelo nome. Os assistidos olharam para as sacolas com pães e o Agente 1 logo explicou que estavam levando para o "Prédio da Caixa" -como eles chamam o Edifício. Assim, eles conversam rapidamente:

18 O Edifício citado tem o nome oficial "Edifício Nossa Senhora da Conceição", embora no letreiro da fachada esteja escrito Edifício Amaral Peixoto. Popularmente, no entanto, é mais conhecido como "Prédio da Caixa", por estar localizado ao lado da Caixa Econômica na Avenida Ernani do Amaral Peixoto. Segundo os moradores do local, a situação dos moradores do Edifício é mista: do $1^{\circ}$ ao $4^{\circ}$ andar faz parte de uma reocupaçáo e a partir do $5^{\circ}$ andar (até o $11^{\circ}$ ) seriam residentes legais. $\mathrm{O}$ prédio fica numa distância aproximada de $1,6 \mathrm{~km}$ do Terminal Rodoviário. 
Assistido 8: Oi, como vocês estão? Estou sumido de lá. Mas eu estou lá... Ele parou de falar, porque os agentes se voltaram ao outro assistido.

Agentes 1 e 3: Oi, irmão, cumprimentam-no apertando a mão.

Assistido 9: $\mathrm{Oi}$, como vocês estão?

Agentes 1 e 3: Estamos bem, irmão. E você?

Assistido 8: Mas o padre ainda está lá na Catedral? ${ }^{19}$

Agente 1: Tá sim. Tá sim.

Assistido 8: Ah! E...

Agente 1: Gente, a gente tá muito atrasado, afirma interrompendo o assistido.

Assistidos 8 e 9: Tá bom. Tá bom.

Assistido 8: Eu tô lá...

Agentes 1 e 3: Tchau. Tchau.

Esse noema mostra que embora um dos assistidos não seja conhecido pelos agentes, tal fato não se tornou empecilho para a tentativa de uma proximidade e de diálogo, mesmo que de maneira simplista e rápida. Também se nota que a pressa é inimiga, não somente da perfeição, mas também da acolhida por completa com todos os afetos e cuidados com o outro. Apesar de estarem se deslocando para um outro compromisso, os agentes ao encontrarem os assistidos " 8 " e " 9 " falam com eles de maneira rápida, não concedendo muito espaço para a construção de um diálogo mais afetivo e profundo. É evidente que há uma pressa por parte dos agentes, que estavam atrasados para outro compromisso, mas, ainda assim, é importante se ter o cuidado para com os que são encontrados "durante" a caminhada, de forma que as práticas da hospitalidade e da convivência não caiam na convencionalidade e sejam feitas de maneira rasa.

Caminhando, o Agente 1 disse ao Agente 3 que estava mal por não ter conversado com os assistidos 8 e 9 devido ao atraso, que estava sentido falta dos "papos" com o Assistido 8 na Catedral, mas que não teve como parar, porque estava "preocupado de chegar ao final da festinha". (...). Ao chegarem ao quarteirão, os agentes já avistam a Assistida 10 e o Assistido 11, ambos são crianças, que estavam correndo, brincando e sorrindo. Ao enxergar o Agente 3 , a assistida usa dele para desviar do colega que estava correndo atrás dela. Ainda no caminho, ela o abraça o parabenizando-o pelo seu aniversário que era no mesmo dia; também abraça o Agente 1. Ela, ao abraçar os agentes, fazia-o com sorriso no rosto e respiração ofegante, visto que estava correndo.

(...) Chegando até o local, o Agente 1 se desculpa com os agentes e assistidos que estavam na confraternizaçáo. (...) A Agente 6 - voluntária de outro grupo -, que já estava aguardando os pães, prepara os cachorros-quentes enquanto os agentes 1 e 3 conversam com os assistidos:

Agente 1: Oi, como vai?, cumprimenta beijando-a no rosto.

Assistida 12, mãe da assistida 10: Vou bem, responde sorrindo após o beijo de cumprimento. E você?, perguntou.

Agente 1: Vou bem. E você, como vai?, dirigindo-se à Assistida 13 que estava ao lado dela.

Assistida 13: Vou bem, responde com uma criança no colo.

Agente 1: Qual é o nome? Olhaaa... que lindo.

Ela responde o nome.

19 Catedral Metropolitana São João Batista, Niterói-RJ. 
Todos começam a comer cachorro quente.

Agente 1: Oiiii, como vai? Saudades.

Assistida 14: Oi, responde surpresa. Vou bem. Verdade, saudades.

Agente 3: Oiii...

Assistida 14: Oiii.

Já na chegada dos agentes no compromisso marcado, através de abraços e cumprimentos, torna-se evidente a acolhida e toda a hospitalidade que há naquele lugar. Falamos de uma hospitalidade, que vem tanto por parte dos agentes, que abraçam e cumprimentam a todos, mas também por parte dos assistidos, que através da abertura que é feita, adentram nessa acolhida sem reservas e filtros; e também enriquecem o espaço de convivência com suas partilhas de afetos. Além disso, não só nesse recorte específico, mas em outros noemas anteriormente analisados, inferese que dentro desse espaço de interaçáo, a alteridade que há entre os assistidos e os agentes é acolhedora, não somente usada para sustentar uma interação vertical, mas sim, uma interação onde todos os sujeitos, com suas especificidades e vivências, são ativos nesse espaço de convivência.

Agente 1: Vai comer um cachorro-quente.

Agente 3: Quero não.

Agente 1: Come sim. É para se "fazer um" com eles. Se mostrar igual.

Agente 3: Tá. Já vou.

A Assistida 14 estava de olho na conversa.

Agente 1: Tô falando para ele comer. Eu não como. Não como carne.

Agente 3: É... Não come carne.

Ao falar com o "Agente 3", para ele também comer um cachorro-quente, há por parte do "Agente 1" o desejo de que os agentes se mostrassem iguais aos assistidos, a fim de que não houvesse por parte daqueles, uma recessão causada pela ideia de inferioridade, ou por sentirem a ausência de uma confortabilidade. Tal atitude implica diretamente na ideia de que ser hospitaleiro transcende $o$ ato de somente conceder uma abertura ao outro, mas também se alinha à ação, na qual vivências diferentes se cruzam, permitindo que as práticas da convivência e da hospitalidade aconteçam de maneira autêntica, não se resumindo apenas à ação de coexistir, mas sim de serem ativos de maneira coletiva, reafirmando os laços de proximidades (PEREIRA; SALGUEIRO, 2020).

\section{Noema 5 - 23 de dezembro de 2018}

Neste dia, fizeram uma ceia de natal no Edifício Amaral Peixoto, na Avenida Ernani do Amaral Peixoto. Os agentes da missão Discípulos de Assis juntos com outras pastorais católicas e líderes não católicos fizeram com algumas 
pessoas que dormem na rua ${ }^{20}$ e com moradores do prédio, que também pegam comida na rua com os grupos. Houve uma celebraçáo ecumênica com um líder católico e um anglicano antes dos "comes e bebes". Após a celebração, o Agente 1 organizou uma peça de teatro sobre o nascimento de Jesus com os assistidos que estavam lá, os quais se empolgaram bastante em participar, caracterizando-se com as roupas que o agente havia levado. Foi muito divertido para todos. Em seguida, a ceia foi liberada e todos comeram o quanto quiseram além de levar para as suas casas e para seus lugares nas calçadas. Após algumas horas envolvendo a celebração, a peça e a ceia, houve a distribuição de presentes para as crianças através do Papai Noel - um dos agentes pastorais.

A ceia de Natal tem um grande significado para aqueles que a comemoram; para muitos, trata-se de uma comemoração, onde se tem a oportunidade de ter por perto amigos e familiares e, de maneira mais geral, pessoas pelas quais se tem um afeto. Diante disso, ao entender a oportunidade de os assistidos participarem dessa comemoração, é inquestionável que tal ação é a mais real prova de hospitalidade. Destaca-se que se trata de uma hospitalidade que não é confundida com um sentimentalismo, ou apenas com atos relacionados ao afeto, mas uma hospitalidade que, em prática, vê a alteridade que há no outro, não como um pretexto para uma não abertura, mas como uma oportunidade de tornar aquele espaço mais rico, através do cruzamento vivências e realidades diferentes. Além de todo conforto e acolhida que os assistidos receberam, o ato do "Agente 1", de organizar uma peça com os assistidos, na qual eles foram protagonistas, usando roupas que os assemelhavam aos personagens da peça, aponta para a potencialização dos assistidos dentro da prática da hospitalidade, onde há uma crença na autonomia deles, enxergando-os como pessoas que também podem agregar com suas experiências e vivências ao espaço e ao desenvolvimento dos envolvidos, vendo-os como atores ativos na construção dos laços relacionais. Essa ação por parte do "Agente 1" firma o entendimento de que a abertura ao outro não representa a perda do controle sobre o nosso espaço, e que, o mesmo espaço, de fato, torna-se mais rico pela novidade que é oferecida por quem adentrou nele (BAPTISTA, 2005).

\section{CONSIDERAÇÓES FINAIS}

Vivendo num mundo contemporâneo, no qual, cada vez mais, filosofias morais naturalizam as práticas de marginalização e invisibilização de indivíduos no espaço urbano, sendo eles, verdadeiramente, lançados à própria sorte por sobrevivência. As pessoas em situaçáo de rua se colocam no lugar mais perverso deste panorama. Carecendo das necessidades físicas, afetivas e de cuidado mais básicas, não perdem sua voz, mas raramente encontram ouvidos dispostos a os ouvirem. Não por acaso,

20 Com base em diálogos informais, os moradores do edifício - mesmo os que estão em situação de maior vulnerabilidade, que descem frequentemente para pegar os alimentos trazidos pelos grupos de voluntários que entregam comida no local - não costumam ser tão hospitaleiros com as pessoas que estão em situaçáo de rua, náo permitindo que a maior parte desses participe de atividades no prédio. 
antes de pensarmos numa ética prática para açóes com essas pessoas, reiteramos a necessidade de uma ética da atenção e de uma ética do cuidado dispostas à escuta dos apelos (ou mesmo apenas dos sinais), daqueles fragilizados que sofrem e que sentimos termos o dever de evitar, no mínimo, que esse sofrimento se agrave por conta de uma solidão existencial (CARVALHO, 2015).

Para tal, apresentamos neste artigo (e esperamos ter conseguido demonstrar) a possibilidade - e, por que não, a necessidade - de uma Pedagogia Social de Rua, centrada na convivência e visando construir, em cada prática socioeducativa com esses grupos, verdadeiros lugares de hospitalidade. Tal tarefa, logicamente, não é simples; se, como educadores, sabemos da dificuldade de criar locais de acolhimento e hospitalidade em espaços educacionais mais estruturados e estáticos, quem dirá em locais de tantas imprevisibilidades como nas ruas.

No entanto, como destacou Grinover (2015) ao investigar a nova constituição do espaço urbano, não são os lugares em si que possuem hospitalidade, mas sim, o uso que se faz desses, possibilitando (ou não) a presença de tal elemento em dado local. Assim, a significação de um lugar não está intrinsecamente dada, mas aberta, possibilitando uma construçáo conjunta dos agentes ali presentes. Dessa forma, não é o espaço que é hospitaleiro por natureza, mas seu uso, sua ocupação, sua experiência, fazendo com que todo lugar possa vir a se tornar um lugar de hospitalidade.

Por fim, infere-se que o caminho para tais práticas é árduo, mas não utópico e muito menos impossível. Mesmo sem poder perder de vista, obviamente, que grande parte dessas pessoas tem como necessidade primeira (e mais urgente) a providência material, do alimento, não podemos confundir as práticas socioeducativas nas ruas com meras ações assistencialistas (e, consequentemente, paternalistas). Como táo bem a Missão encarna em seus princípios e práticas, são necessidades prioritárias, também, as dedicaçóes afetivas, a partir das relaçôes interpessoais estabelecidas, e de garantia de direitos, visando uma formação e emancipação cidadã desses assistidos. E é a partir dos princípios das Pedagogias da Convivência e da Hospitalidade que acreditamos ter mais chance disso ocorrer, ansiando por relaçóes de abertura verdadeira para com esse outro, ajudando-o a se libertar das duras violências sofridas na rua. Mas, sabemos que é dele o papel ativo final, rememorando uma pedagogia que nos demonstra que o objetivo maior de toda prática é a possibilidade de autonomia e libertaçáo de seu educando.

\section{REFERÊNCIAS}

BAPTISTA, Isabel. Dar rosto ao Futuro: A educação como compromisso ético. Porto: Profediçôes, 2005.

. Ética, Deontologia e Avaliação do Desempenho Docente. Cadernos do CCAP 3. Ministério da Educação - Conselho Científico para a Avaliação de Professores. Lisboa, 2011. 
Hospitalidade e eleição intersubjectiva: sobre o espírito que guarda os lugares.

Revista Hospitalidade. São Paulo, ano V, n. 2, pp. 5-14, 2008.

CALIMAN, Geraldo. Pedagogia Social no Brasil: evolução e perspectivas. Orientamenti Pedagogici, v. 58, pp. 485-503, 2011.

CARVALHO, Adalberto Dias de. Os Novos Parâmetros Antropológicos da Ética da Hospitalidade. Revista Cadernos de Pedagogia Social - Hospitalidade, Educação e Turismo, Porto - Portugal, Edição Especial, p. 7-16, 2015.

CHINAZZO, Susana Salete Raymundo. O que é fenomenologia? In:

Epistemologia das ciências sociais. Curitiba: InterSaberes, 2013.

DEPRAZ, Natalie. Compreender Husserl. Petrópolis: Vozes, 2011.

FERREIRA, Arthur Vianna. O uso da fenomenologia nas práticas de estágio supervisionado para licenciaturas. Rev. Brasileira de Ensino Superior. Passo Fundo, v. 1, n. 2, pp. 5-14, 2015.

Pedagogia Social e Docência ampliada no processo de formação inicial. In: FERREIRA, Arthur Vianna (org.) - Dentro ou fora da sala de aula? O lugar da pedagogia social. Curitiba: CRV, 2018.

FERREIRA, Arthur Vianna; SIRINO, Marcio Bernardino; MOTA, Patricia Flavia. A autonomia, a convivência e a hospitalidade como formas de construção de práticas socioeducativas na Educação Integral e(m) Tempo Integral. In: Pedagogia social e Educaçáo Integral. $1^{a}$ ed. São Paulo: Pimenta Cultural, 2018.

FERREIRA, Arthur Vianna; SIRINO, Marcio Bernardino; MOTA, Patricia Flavia. Para além da significação 'formal', 'não formal' e 'informal' na educação brasileira. Interfaces Científicas - Educaçáo, v. 8, n. 3, p. 584-596, 2020.

GRACIANI, Maria Stela Santos. PEDAGOGIA SOCIAL DE RUA: Análise e sistematização de uma experiência vivida. São Paulo: Cortez Editora, 1999.

GRINOVER, Lúcio. A Hospitalidade na Perspectiva da Cidade Contemporânea. Revista Cadernos de Pedagogia Social - Hospitalidade, Educação e Turismo, Porto - Portugal, Ediçãao Especial, p. 162-177, 2015.

JARES, Xesús Rodriguez. Educação para a Paz: sua teoria e prática. Porto Alegre, Artmed, 2002.

Educar para a paz em tempos difíceis. São Paulo, Palas Athena, 2007.

Pedagogia da Convivência. São Paulo, Palas Athena, 2008.

LIBERALESSO, Rita de Cacia Borges. A EDUCAÇÃO SOCIAL DE RUA E OS PRESSUPOSTOS EDUCACIONAIS FREIREANOS. Educere et Educare - Revista de Educação, v. 3, n. 5, pp. 117-123, jan./jun., 2008. 
LOPES, Lucas Salgueiro. EDUCAÇÃO PARA PAZ-CIDADANIA: as (possíveis) práticas socioeducativas num pré-vestibular comunitário no Complexo do Salgueiro em São Gonçalo-RJ. In: FERREIRA, Arthur Vianna; LOPES, Lucas Salgueiro; DIAS, Thiago Simão. (Org.). Fora da Sala de Aula: Formação Docente e Pesquisas sobre Pobreza e Educação. $1^{\mathrm{a}}$ ed. Rio de Janeiro: Autografia, 2019.

\section{. REFLEXÓES SOBRE A FORMAÇÃO DOCENTE PARA TEMAS ACERCA}

DA CRENÇA NA PERFECTIBILIDADE E EDUCABILIDADE HUMANA. In: FERREIRA, Arthur Vianna; LOPES, Lucas Salgueiro; DIAS, Thiago Simão (Org.).

Educaçáo, Hospitalidade e Pobreza. 1a ed. Rio de Janeiro: Autografia, 2020.

LOPES, Lucas Salgueiro; FERREIRA, Arthur Vianna. A fenomenologia como possibilidade de método investigativo em pesquisas educacionais. MOVIMENTO Revista de Educaçáo. Niterói: ano 6, no 10, p. 219-238, jan./jun., 2019.

MACHADO, Érico Ribas. A Pedagogia Social no contexto brasileiro: análises de possíveis aproximações ou distanciamentos das áreas de Educação Popular e dos Movimentos Sociais. In: III CONGRESSO INTERNACIONAL DE PEDAGOGIA SOCIAL, São Paulo, 2010.

. Fundamentos da Pedagogia Social. Paraná: Editora Unicentro, 2013.

OTTO, Hans-Uwe. Origens da pedagogia social. In: SOUSA NETO, João Clemente de; SILVA, Roberto da; MOURA, Rogério. (Orgs.). Pedagogia Social. Vol. 1, 2a edição. São Paulo: Expressão e Arte, 2011.

PAIVA, Jacyara Silva. Caminhos do Educador Social no Brasil. São Paulo: Paco Editorial, 2015.

PEREIRA, Débora Simeão Ortman; LOPES, Lucas Salgueiro. CONVIVER REQUER HOSPITALIDADE: pensando modelos de práticas socioeducativas a partir dos diálogos entre as Pedagogias da Hospitalidade e da Convivência. In: FERREIRA, Arthur Vianna; LOPES, Lucas Salgueiro; DIAS, Thiago Simão (Org.). Educação, Hospitalidade e Pobreza. 1a ed. Rio de Janeiro: Autografia, 2020.

SILVA, Filipi José da. A PEDAGOGIA DA CONVIVÊNCIA COMO MÉTODO DE ANÁLISE DO CAMPO DE ATUAÇÃO E ESTUDO DA PEDAGOGIA SOCIAL. In: FERREIRA, Arthur Vianna; LOPES, Lucas Salgueiro; DIAS, Thiago Simão. (Org.). Fora da Sala de Aula: Formação Docente e Pesquisas sobre Pobreza e Educação. $1^{\text {a }}$ ed. Rio de Janeiro: Autografia, 2019.

. OI, QUER UM LANCHE? - "eu” e o "outro" nas ruas de Niterói-RJ a partir da ótica da hospitalidade. In: FERREIRA, Arthur Vianna; LOPES, Lucas Salgueiro; DIAS, Thiago Simão (Org.). Educaçáo, Hospitalidade e Pobreza. $1^{\text {a }}$ ed. Rio de Janeiro: Autografia, 2020. 